\title{
The Twenty-Sixth Annual Meeting, July 1997
}

The Twenty-Sixth Annual Meeting of the College was held at the Bournemouth International Centre, Bournemouth, on 1-4 July 1997.

\section{Business Meeting}

The Business Meeting of the Royal College of Psychiatrists was held on Wednesday 2 July 1997 and was chaired by the President. Dr Robert Kendell. It was attended by 54 members of the College.

The minutes of the previous meeting held in London on 9 July 1996, and published in the Psychiatric Bulletin. December 1996, were approved and signed.

The Report of the President was received. The Report of the Registrar and the Annual Report were received and approved. The Report of the Treasurer and the Annual Accounts for 1996, as given in the College's Annual Report, were received and approved. The re-appointment of the auditors was approved. The new fees and subscription rates from 1 January 1998 were approved. The Report of the Dean was received. The Report of the Editors was received. The Report of the Librarian was received.

\section{President's Report}

The President reported on the action that had occurred since the Resolution on community care which had been passed at the Annual Meeting in 1996. The College was collecting accurate data, and the Research Unit had carried out the fifth MILMIS survey (Monitoring Inner-London Mental Illness Services). Over the past three years there had been no change in the overcrowding of beds and the number of extra-contractual referrals. The President outlined the preliminary results of the College's Manpower Census, which was almost complete.

The College's Resolution had had an effect upon Government Ministers. The then Secretary of State, Mr Stephen Dorrell, had given the opening presentation at the College's Conference on Manpower in late 1996. In February 1997 the Registrar and President had met Mr Dorrell, who had agreed with the College's analysis of the situation. At that meeting, the President had emphasised the urgent need for a substantial number of 24-hour nursed beds (5000), and had urged that mandatory homicide inquiries should cease.

The President was due to meet Mr Paul Boateng. Parliamentary Under-Secretary, Department of Health, and Mr Alan Langlands, Chief Executive of the NHS Executive.

Finally, the President reported that a questionnaire on College services would shortly be sent to a random sample of College members.

\section{Registrar's Report}

The Registrar, Professor Chris Thompson, outlined the extensive changes in the College's structures which came into effect at the meeting.

The Social Community and Rehabilitation Section and the General Psychiatry Section ceased to exist and were replaced by the Faculty of General and Community Psychiatry and the Section of Rehabilitation and Social Psychiatry. The Liaison Psychiatry Group became a Section. All other Specialist Sections became Faculties, with representation on the Executive and Finance Committee and on Council.

Changes to the titles and boundaries of some of the College Divisions in England now came into effect, to bring them in line with the NHS Executive Regional Offices. The former Chiltern and Thames Valley and East Anglian Divisions were replaced by the North Thames Division and the Anglia and Oxford Division. The Midlands Division was replaced by the West Midlands and Trent Divisions. Representation of the Divisions on Council was rationalised, reducing the membership of Council.

The Registrar also described in detail the changes to the College's Committee structure which had been agreed at the recent meeting of Council, and would shortly come into effect.

Finally, the Registrar congratulated Dr Mike Shooter as his successor, and expressed his thanks to members of the College, to his fellow Officers, and to College staff.

\section{Treasurer's Report}

The Treasurer, Professor Issy Kolvin, reported that the College's financial position was continuing to improve. The College had emerged from 1996 with a small deficit being converted into a healthy financial surplus. The Treasurer anticipated that this trend would continue, provided that systems of financial monitoring and tight financial controls were maintained. A set of procedures had been instituted to ensure (a) the reduction of irrecoverable VAT; (b) the reduction of levels of irrecoverable debts; and (c) that conference income covered expenditure. Systems of budgeting had been established, and 
these were monitored by the Finance Management Committee. Recent industrial action, a rare event in the College, had, however, added to the costs. The Treasurer emphasised that the professional skills in the Finance Department had contributed substantially to the healthier financial picture.

The Treasurer described the achievements of individual College departments in the previous year, and reported with satisfaction that the College's Bankers had agreed to remove the lien on the College property. A full account of achievements and new developments relating to the College's finances is given in the 1997 Annual Report.

\section{Dean's Report}

The Dean, Professor John Cox, detailed the proposed changes to the College's committee structure, which it was anticipated would facilitate continuity of thought from General Professional Training through to Higher Professional Training and Continuing Professional Development (CPD).

The Multiple Choice Question (MCQ) section of the MRCPsych examination was under particular scrutiny. The Court of Electors had agreed that candidates who had irrevocably failed the Part I MCQ should not proceed to the clinical examination. A Critical Review Paper was to be introduced in 1999.

The new Specialist Registrar grade had been introduced, and detailed criteria agreed for the award of Certificates of Completion of Specialist Training in six specialities.

The Overseas Doctors Training Scheme had expanded considerably, placing such doctors in one of three programmes: Overseas Sponsorship. UK Consultant Assisted Sponsorship and University-based schemes.

Flexible Training issues were now being coordinated by the Department of Postgraduate Educational Services, and it was hoped that a more direct College policy on these training issues would become possible. A survey of flexible trainees was planned to assist in this development.

The Dean reported that the Collegiate Trainees' Committee continued to flourish and contribute most actively to all aspects of College life.

\section{Editor's Report}

The Editor, Professor Greg Wilkinson, reported another successful year in the Publications Department. He thanked Professor Andrew Sims. Editor of Advances in Psychiatric Treatment, and Dr Alan Kerr, Editor of the Psychiatric Bulletin. for their continuing help and support. The Editor announced that Dr Kerr would become Deputy Editor of the British Journal of Psychiatry on 1 January 1998. Finally, the Editor thanked all those involved in the College and outwith for their outstanding contributions to the effectiveness and utility of Publications, and looked forward to further achievements on behalf of the College in the years to come.

\section{Librarian's Report}

The Honorary Librarian, Dr Ian Pullen, reported an increased use of the Library and Information Service over the past year, particularly in relation to literature searches. A review of charges for library services had been undertaken, with new charges reflecting the true cost to the College. Members would continue to receive up to four searches each calendar year before attracting charges.

The book collection had continued to reflect contemporary publications by the membership. The Honorary Librarian thanked members who had donated copies of their works to the Library during the last year. Unfortunately, there had been a fall in the proportion of members who had responded positively to an invitation to make such donations.

Library publications, including the Trainees' Reading Lists, were being updated. 